\title{
Clinicopathological Characteristics and Prognostic Factors in Axial Chondroblastomas: A Retrospective Analysis of 61 Cases and Comparison with Extra- Axial Chondroblastomas
}

\section{Bo-Wen Zheng}

Second Xiangya Hospital

Bo-Yv Zheng

Second Xiangya Hospital

Hua-Qing Niu

Second Xiangya Hospital

Xiao-Bin Wang

Second Xiangya Hospital

Guo-Hua Lv

Second Xiangya Hospital

Jing Li

Second Xiangya Hospital

Ming-Xiang Zou

Second Xiangya Hospital

Zhi-Hua Ouyang ( $\square$ zouwei8887@126.com )

Second Xiangya Hospital https://orcid.org/0000-0002-9308-3794

\section{Research Article}

Keywords: Axial chondroblastomas, Extra-axial chondroblastomas, Prognostic factors, Survival, Comparative study

Posted Date: February 4th, 2022

DOI: https://doi.org/10.21203/rs.3.rs-1242480/v2

License: (1) This work is licensed under a Creative Commons Attribution 4.0 International License. Read Full License 


\section{Abstract}

Background: The clinical characteristics and prognostic factors of axial chondroblastoma (ACB) are still poorly understood.

Purpose: To characterize clinicopathological characteristics in a large ACB cohort and investigate their correlation with survival. We also sought to compare these results with extra-axial CB (EACB).

Methods: Our institution's local database was retrospectively reviewed and included a total of $132 \mathrm{CB}$ patients, including 61 ACB patients and 71 EACB patients. Immunohistochemistry was used to assess the expression levels of Vimentin (Vim), S100, and cytokeratin (CK) on tumor cells in 132 tissue specimens.

Results: Overall, ACB and EACB had similar characteristics, except for older age and tumor size, as well as higher Vim expression, incidence of surrounding tissue invasion and postoperative sensory or motor dysfunction. Whereas wide resection and absence of invasion of surrounding tissues were consistently associated with favorable survival in the ACB and EACB cohorts in univariate analysis, most parameters showed differential prognostic significance between the 2 groups. Significant prognostic factors for local recurrence-free survival in multivariate analysis included the type of resection and chicken-wire calcification in the ACB cohort. Multivariate analysis of overall survival demonstrated that the type of resection was a significant predictor in the ACB cohort, whereas the type of resection and postoperative sensory or motor dysfunction were predictive of overall survival in the EACB group.

Conclusion: These data suggest that there may be distinct biological behaviors between ACB and EACB and may provide useful information to better understand the prognostic characteristics of patients with ACB and to improve outcome prediction in patients with ACB.

\section{Introduction}

Chondroblastoma (CB) is a rare cartilage-derived tumor with locally aggressive growth characteristics that most often involves the long bone epiphysis and is less than $1 \%$ of all bone tumors ${ }^{1}$. The current treatment for $\mathrm{CB}$ relies on complete resection of the tumor, but due to the locally aggressive nature of the tumor and its possible proximity to important neurovascular structures, surgery may have difficulty obtaining extensive complete resection of the tumor; in addition, conventional chemotherapy is ineffective in $\mathrm{CB}$ patients, and radiotherapy may even cause disease malignancy ${ }^{2}$. Therefore, the recurrence rate of $\mathrm{CB}$ patients after surgery is high, which seriously affects the long-term quality of life and survival of patients.

$\mathrm{CB}$ occurs mostly in regions other than the axial bone, most commonly in the metaphysis of the long bones ${ }^{1}$, and current studies on $\mathrm{CB}$ have also focused on $\mathrm{CB}$ of the extremity bones. Previous studies have found that the biological behavior of $\mathrm{CB}$ affects the clinical outcome of patients and that tumors located in the proximal pelvis and humerus are prone to recurrence after surgery 3,4 . Patient age and cyst formation have also been reported to be associated with $C B$ recurrence ${ }^{4-6}$. These findings provide useful 
information for the prognostic risk stratification of extra-axial CB (EACB) and the development of new treatment strategies.

Compared with EACB, axial chondroblastomas (ACB) are much rarer, with cranial $\mathrm{CB}$ accounting for less than $2 \%$ of all $C B$ patients and a much higher probability of recurrence in patients with postoperative residual lesions in cranial $\mathrm{CB}^{7}$; spinal $\mathrm{CB}$ accounts for only $1.4 \%$ of all $\mathrm{CB}$ patients ${ }^{8}$ and is more likely to recur than extremity $\mathrm{CB}$. Spinal $\mathrm{CB}$ is more prone to recurrence and more aggressive tumor growth than extremity $\mathrm{CB}^{9-11}$. To date, although studies on $\mathrm{ACB}$ have been reported in the literature, most of them are single cases or small case series. Considering the poor prognosis of ACB, a systematic summary of prognostic factors and reasonable risk stratification of patients would help optimize the treatment plan and thus improve the survival prognosis of patients. In this study, we aimed to summarize the clinicopathological characteristics of patients with ACB and identify the factors affecting local recurrence-free survival (LRFS) and overall survival (OS) through a comprehensive analysis of a large sample of $\mathrm{CB}$ cases. We also compared the differences between the clinicopathological characteristics of $\mathrm{ACB}$ and EACB.

\section{Methods And Materials}

\section{Patients and tissue samples}

A total of 132 patients (including 61 patients with $A C B$ and 71 patients with EACB) were included. Patient characteristics were recently communicated by our group ${ }^{12}$. In addition, basic patient and tumor characteristics, treatment history, and clinical outcome data were obtained from the patients' medical records. Extracted clinical information included patient demographics (age and sex), clinical features (including duration of symptoms, preoperative and postoperative sensorimotor status), and patient treatment modality (type of surgery and adjuvant radiotherapy). Surrounding tissue invasion by tumors was evaluated by preoperative magnetic resonance imaging (MRI). The pathological diagnosis was independently confirmed by two neuropathologists based on hematoxylin and eosin (HE)-stained sections and pathology (presence of secondary aneurysmal bone cyst $[A B C]$ and chicken-wire calcification). The main events were LRFS and OS. The former was defined as the time interval from tumor resection to the first tumor recurrence and was recorded as LRFS; the latter was defined as the length of time from surgical resection of the tumor to the patient's all-cause death and was recorded as $\mathrm{OS}^{12}$. According to a previously reported method ${ }^{13}$, the type of surgical resection was determined as extensive resection (such as gross total or en bloc resection with negative margins) or not extensive resection (including intralesional or marginal resection).

\section{Immunohistochemistry Staining and Evaluation}

Immunohistochemistry was performed as previously described ${ }^{12}$. Briefly, paraffin-embedded sections of specimens $(4 \mu \mathrm{m})$ were dewaxed in xylene and rehydrated with a series of graded ethanol solutions, followed by rinsing in distilled water. After antigen recovery and closure, tissue sections were incubated 
with anti-Vimentin [Vim] (Abcam company) at a dilution of 1:400, anti-S100 (Abcam company) at a dilution of 1:100, and anti-cytokeratin [CK] (Abcam company) at a dilution of 1:20 overnight at $4^{\circ} \mathrm{C}$. After treatment with secondary biotinylated goat anti-rabbit or anti-mouse immunoglobulins, sections were incubated with the antibiotic protein streptavidin-peroxidase conjugate (Auragene, Changsha, Hunan, China) and then visualized with 3,3-diaminobenzidine solution and preserved with hematoxylin.

The results of immunohistochemical staining were evaluated independently by two neuropathologists (Y.J. and X.L.S.) with deep expertise in the field of neuro-oncology. Positive expression for S100, Vim, and CK was defined by the presence of yellow or brownish-yellow granules at the corresponding site. Five high magnification fields were randomly observed in each section, the proportion of staining in each field was counted, and the mean value was taken. The expression level of each immunohistochemical index was assessed in HE sections and evaluated as absent (0), rare/rare (1), moderate (2), or significant (3) according to a previously published method ${ }^{14}$. Tissue samples were then judged as negative if a score of 0-1 was observed and positive otherwise.

\section{Statistical analysis}

X-tile software version 3.6.1 (https://medicine.yale.edu/lab/rimm/research/software.aspx) was used to determine the threshold for age, duration of symptoms, and tumor size in survival analysis, with OS as the outcome parameter ${ }^{15}$. The point corresponds to the minimum $p$ value of the corrected log-rank test ${ }^{16}$. Patients were divided into two subgroups ( $\leq$ cutoff or $>$ cutoff) according to the cutoff point. Specifically, this threshold value was defined as the point with the minimum $P$ value from the log-rank test, which was corrected accordingly ${ }^{17}$. All statistical analyses were completed using SPSS 26.0 software (SPSS, IBM, Armonk, New York). Data were described using the mean \pm standard deviation, and statistical comparisons were completed using t test or ANOVA; categorical data were expressed using frequency or composition ratio, and statistical analyses were performed using the chi-square test. A univariate Kaplan-Meier curve by log-rank test was used for one-way survival analysis to explore the relationship between clinicopathological parameters and patient outcomes. A multivariate Cox proportional hazards model was used to analyze independent risk factors for patients' LRFS and OS, and only variables that were statistically significant for univariate survival analysis were included in the analysis. All hypothesis tests were two-sided and considered statistically significant when $\mathrm{P}<0.05$.

\section{Results}

\section{Patient and tumor characteristics of CB Patients}

A total of 132 patients with CB were included in this study. Among them, 61 patients had ACB, and 71 patients had EACB (Figure 1). The characteristics of the patients are shown in Table 1. All patients underwent surgery, including 65 wide resections and 67 nonwide resections. No patients received chemotherapy. Thirty-four patients underwent postoperative adjuvant photon radiotherapy. Age, tumor size, and symptom duration were used as subgroup cutoffs for OS survival analysis in patients with ACB 
and EACB, as shown in Figure 2 and Figure 3. Representative pictures of immunohistochemical markers are shown in Figure 4. 
Table 1

Comparison of baseline characteristics between axial chondroblastoma and extra-axial chondroblastoma

\begin{tabular}{|c|c|c|c|c|c|}
\hline Variable & Categories & All (n) & axial (n) & $\begin{array}{l}\text { extra-axial } \\
\text { (n) }\end{array}$ & $\begin{array}{l}P \\
\text { value }\end{array}$ \\
\hline Age (years) & Continuous & $\begin{array}{l}132 \\
(29.2 \pm 13.4)\end{array}$ & $\begin{array}{l}61 \\
(34.1 \pm 14.6)\end{array}$ & $\begin{array}{l}71 \\
(24.9 \pm 10.8)\end{array}$ & $<0.001$ \\
\hline \multirow[t]{2}{*}{ Gender } & Female & 46 & 19 & 27 & 0.408 \\
\hline & Male & 86 & 42 & 44 & \\
\hline $\begin{array}{l}\text { Duration of symptoms } \\
\text { (months) }\end{array}$ & Continuous & $\begin{array}{l}132 \\
(8.3 \pm 7.4)\end{array}$ & $\begin{array}{l}61 \\
(8.3 \pm 6.7)\end{array}$ & $\begin{array}{l}71 \\
(8.3 \pm 8.1)\end{array}$ & 0.955 \\
\hline Tumor size (in diameter, cm) & Continuous & $\begin{array}{l}132 \\
(3.9 \pm 1.8)\end{array}$ & $\begin{array}{l}61 \\
(5.3 \pm 1.5)\end{array}$ & $\begin{array}{l}71 \\
(2.6 \pm 0.9)\end{array}$ & $<0.001$ \\
\hline \multirow[t]{2}{*}{ Type of resection } & Wide & 65 & 27 & 38 & 0.289 \\
\hline & Not wide & 67 & 34 & 33 & \\
\hline \multirow[t]{2}{*}{ Surrounding tissue invasion } & No & 59 & 12 & 47 & $<0.001$ \\
\hline & Yes & 73 & 49 & 24 & \\
\hline \multirow[t]{2}{*}{ Adjuvant radiotherapy } & No & 98 & 44 & 54 & 0.607 \\
\hline & Yes & 34 & 17 & 17 & \\
\hline \multirow{2}{*}{$\begin{array}{l}\text { Preoperative sensory or motor } \\
\text { dysfunction }\end{array}$} & No & 97 & 39 & 58 & 0.021 \\
\hline & Yes & 35 & 22 & 13 & \\
\hline \multirow{2}{*}{$\begin{array}{l}\text { Postoperative sensory or motor } \\
\text { dysfunction }\end{array}$} & No & 53 & 20 & 33 & 0.110 \\
\hline & Yes & 79 & 41 & 38 & \\
\hline \multirow[t]{2}{*}{ Secondary $A B C$} & No & 74 & 33 & 41 & 0.674 \\
\hline & Yes & 58 & 28 & 30 & \\
\hline \multirow[t]{2}{*}{ Chicken-wire calcification } & No & 63 & 24 & 39 & 0.074 \\
\hline & Yes & 69 & 37 & 23 & \\
\hline \multirow[t]{2}{*}{ Recurrence during follow-up } & No & 95 & 39 & 56 & 0.057 \\
\hline & Yes & 37 & 22 & 15 & \\
\hline \multirow[t]{2}{*}{ S100 } & Low & 27 & 13 & 14 & 0.821 \\
\hline & High & 105 & 48 & 57 & \\
\hline
\end{tabular}

Bold values indicate $P<0.05 ; \mathrm{ABC}$, aneurysmal bone cyst; Vim, Vimentin; $C K$, cytokeratin. 


\begin{tabular}{|llllll|}
\hline Variable & Categories & All $(\mathbf{n})$ & axial $(\mathbf{n})$ & $\begin{array}{l}\text { extra-axial } \\
(\mathbf{n})\end{array}$ & $\begin{array}{l}P \\
\text { value }\end{array}$ \\
\hline Vim & Low & 37 & 9 & 28 & 0.002 \\
\hline CK & High & 95 & 52 & 43 & \\
\hline & Low & 91 & 42 & 49 & 0.984 \\
\hline Bold values indicate $P<0.05 ;$ ABC, aneurysmal bone cyst; Vim, Vimentin; CK, cytokeratin. & \\
\hline
\end{tabular}

\section{Comparison of Clinicopathological Characteristics Between ACB and EACB Patients}

In a comparison of the ACB and EACB cohorts, the size of the tumors was larger in ACB patients than in EACB patients, and the proportion of surrounding tissue invasion and the incidence of preoperative neuromotor dysfunction were also higher in ACB patients. High expression of Vim was also seen more frequently in ACB patients (Table 1).

\section{Univariate Kaplan-Meier analysis and multivariate Cox analyses of prognostic factors in patients with ACB}

Univariate Kaplan-Meier analysis found that the type of resection and chicken-wire calcification were significantly associated with LRFS (Table 2 and Figure 5). Surrounding tissue invasion, type of resection and chicken-wire calcification significantly influenced OS (Table 2 and Figure 6). Further multivariate Cox analysis showed that the type of resection and chicken-wire calcification were independent predictors of LRFS (Table 3); the type of resection could independently predict OS (Table 3). 
Table 2

Univariate analysis of the prognostic factors of local recurrence-free survival and overall survival in patients with axial chondroblastoma

\begin{tabular}{|c|c|c|c|c|c|c|}
\hline \multirow[t]{2}{*}{ Factors } & \multirow[t]{2}{*}{ Categories } & \multirow[t]{2}{*}{ Numbers } & \multicolumn{2}{|c|}{$\begin{array}{l}\text { local recurrence- } \\
\text { free survival }\end{array}$} & \multicolumn{2}{|c|}{ overall survival } \\
\hline & & & $x^{2}$ & $P$-value & $x^{2}$ & $\begin{array}{l}P \\
\text { value }\end{array}$ \\
\hline \multirow[t]{2}{*}{ Age (years) } & $\begin{array}{l}\text { Young }(\leq \\
\text { cutoffa) }\end{array}$ & 37 & 0.428 & $0.513^{b}$ & 1.399 & $0.237^{b}$ \\
\hline & $\begin{array}{l}\text { Old }(> \\
\left.\text { cutoff }{ }^{a}\right)\end{array}$ & 24 & & & & \\
\hline \multirow[t]{2}{*}{ Gender } & Female & 19 & 1.602 & 0.206 & 2.985 & 0.084 \\
\hline & Male & 42 & & & & \\
\hline \multirow[t]{2}{*}{$\begin{array}{l}\text { Duration of symptoms } \\
\text { (months) }\end{array}$} & $\begin{array}{l}\text { Short }(\leq \\
\left.\text { cutoffa }^{\mathrm{a}}\right)\end{array}$ & 19 & 0.437 & $0.509^{b}$ & 1.409 & $0.235^{\mathrm{b}}$ \\
\hline & $\begin{array}{l}\text { Long (> } \\
\text { cutoffa) }\end{array}$ & 42 & & & & \\
\hline \multirow[t]{2}{*}{ Tumor size (in diameter, cm) } & $\begin{array}{l}\text { Small }(\leq \\
\text { cutoffa) }\end{array}$ & 30 & 0.001 & $0.980^{b}$ & 0.955 & $0.329^{b}$ \\
\hline & $\begin{array}{l}\text { Large (> } \\
\left.\text { cutoff }^{a}\right)\end{array}$ & 31 & & & & \\
\hline \multirow[t]{2}{*}{ Type of resection } & Wide & 27 & 13.795 & $<0.001$ & 10.278 & 0.001 \\
\hline & Not wide & 34 & & & & \\
\hline \multirow[t]{2}{*}{ Surrounding tissue invasion } & No & 18 & 3.675 & 0.055 & 4.041 & 0.044 \\
\hline & Yes & 43 & & & & \\
\hline \multirow[t]{2}{*}{ Adjuvant radiotherapy } & No & 44 & 1.640 & 0.205 & 0.853 & 0.356 \\
\hline & Yes & 17 & & & & \\
\hline \multirow{2}{*}{$\begin{array}{l}\text { Preoperative sensory or } \\
\text { motor dysfunction }\end{array}$} & No & 39 & 0.099 & 0.753 & 0.853 & 0.356 \\
\hline & Yes & 22 & & & & \\
\hline $\begin{array}{l}\text { Postoperative sensory or } \\
\text { motor dysfunction }\end{array}$ & No & 20 & 0.989 & 0.320 & 2.195 & 0.138 \\
\hline
\end{tabular}

Bold values indicate $P<0.05 ; \mathrm{ABC}$, aneurysmal bone cyst; Vim, Vimentin; CK, cytokeratin. ${ }^{\mathrm{a}}$ Cutoff points for patient age, duration of symptoms, tumor size in the survival analysis of OS were 35, 4.0, 5.0 , respectively; ${ }^{b} \mathrm{P}$ value from the log-rank test was corrected as previously suggested. 


\begin{tabular}{|c|c|c|c|c|c|c|}
\hline \multirow[t]{2}{*}{ Factors } & \multirow[t]{2}{*}{ Categories } & \multirow[t]{2}{*}{ Numbers } & \multicolumn{2}{|c|}{$\begin{array}{l}\text { local recurrence } \\
\text { free survival }\end{array}$} & \multicolumn{2}{|c|}{ overall survival } \\
\hline & & & $\chi^{2}$ & $P$-value & $\chi^{2}$ & $\begin{array}{l}P \\
\text { value }\end{array}$ \\
\hline & Yes & 41 & & & & \\
\hline \multirow[t]{2}{*}{ Secondary $A B C$} & No & 33 & 2.636 & 0.104 & 0.156 & 0.693 \\
\hline & Yes & 28 & & & & \\
\hline \multirow[t]{2}{*}{ Chicken-wire calcification } & No & 24 & 11.416 & 0.001 & 5.679 & 0.017 \\
\hline & Yes & 37 & & & & \\
\hline \multirow[t]{2}{*}{ Tumoral S100 expression } & Low & 13 & 0.946 & 0.331 & 0.151 & 0.698 \\
\hline & High & 48 & & & & \\
\hline \multirow[t]{2}{*}{ Tumoral Vim expression } & Low & 9 & 0.109 & 0.741 & 0.001 & 0.974 \\
\hline & High & 52 & & & & \\
\hline \multirow[t]{2}{*}{ Tumoral CK expression } & Low & 42 & 2.920 & 0.088 & 0.668 & 0.414 \\
\hline & High & 19 & & & & \\
\hline \multicolumn{7}{|c|}{$\begin{array}{l}\text { Bold values indicate } P<0.05 ; A B C \text {, aneurysmal bone cyst; Vim, Vimentin; } C K \text {, cytokeratin. }{ }^{a} \text { Cutoff } \\
\text { points for patient age, duration of symptoms, tumor size in the survival analysis of OS were } 35,4.0 \text {, } \\
5.0 \text {, respectively; }{ }^{b} P \text { value from the log-rank test was corrected as previously suggested. }\end{array}$} \\
\hline
\end{tabular}


Table 3

Multivariate cox analyses of the prognostic factors of local recurrence-free survival and overall survival in patients with axial chondroblastoma

\begin{tabular}{|c|c|c|c|c|c|c|}
\hline \multirow[t]{2}{*}{ Factors } & \multirow[t]{2}{*}{ Categories } & \multirow[t]{2}{*}{ Numbers } & \multicolumn{2}{|c|}{$\begin{array}{l}\text { local recurrence-free } \\
\text { survival }\end{array}$} & \multicolumn{2}{|c|}{ overall survival } \\
\hline & & & $\begin{array}{l}P \\
\text { value }\end{array}$ & $\mathrm{HR}(95 \% \mathrm{Cl})$ & $\begin{array}{l}P \\
\text { value }\end{array}$ & $\mathrm{HR}(95 \% \mathrm{Cl})$ \\
\hline \multirow[t]{2}{*}{ Type of resection } & Wide & 27 & 0.002 & $\begin{array}{l}0.137(0.039- \\
0.479)\end{array}$ & 0.027 & $\begin{array}{l}0.097(0.012- \\
0.768)\end{array}$ \\
\hline & Not wide & 34 & & & & \\
\hline \multirow[t]{2}{*}{$\begin{array}{l}\text { Surrounding tissue } \\
\text { invasion }\end{array}$} & No & 18 & / & / & 0.192 & $\begin{array}{l}0.242(0.029- \\
2.039)\end{array}$ \\
\hline & Yes & 43 & & & & \\
\hline \multirow[t]{2}{*}{$\begin{array}{l}\text { Chicken-wire } \\
\text { calcification }\end{array}$} & No & 24 & 0.003 & $\begin{array}{l}3.913(1.583- \\
9.672)\end{array}$ & 0.063 & $\begin{array}{l}3.167(0.938- \\
10.695)\end{array}$ \\
\hline & Yes & 37 & & & & \\
\hline
\end{tabular}

\section{Univariate Kaplan-Meier analysis and multivariate Cox analyses of prognostic factors in patients with EACB}

Univariate Kaplan-Meier analysis found that sex, type of resection, and adjuvant radiotherapy were associated with patient LRFS (Table 4 and Figure 7); type of resection, surrounding tissue invasion, adjuvant radiotherapy, and postoperative sensory or motor dysfunction were associated with patient OS (Table 4 and Figure 8). A multivariate Cox regression model revealed that the type of resection and surrounding tissue invasion could independently predict LRFS (Table 5); the type of resection could independently predict OS (Table 5). 
Table 4

Univariate analysis of the prognostic factors of local recurrence-free survival and overall survival in patients with extra-axial chondroblastoma

\begin{tabular}{|c|c|c|c|c|c|c|}
\hline \multirow[t]{2}{*}{ Factors } & \multirow[t]{2}{*}{ Categories } & \multirow[t]{2}{*}{ Numbers } & \multicolumn{2}{|c|}{$\begin{array}{l}\text { local recurrence- } \\
\text { free survival }\end{array}$} & \multicolumn{2}{|c|}{ overall survival } \\
\hline & & & $x^{2}$ & $P$-value & $x^{2}$ & $\begin{array}{l}P \\
\text { value }\end{array}$ \\
\hline \multirow[t]{2}{*}{ Age (years) } & $\begin{array}{l}\text { Young }(\leq \\
\text { cutoffa) }\end{array}$ & 37 & 0.415 & $0.519^{b}$ & 0.555 & $0.456^{\mathrm{b}}$ \\
\hline & $\begin{array}{l}\text { Old }(> \\
\left.\text { cutoff }^{\mathrm{a}}\right)\end{array}$ & 34 & & & & \\
\hline \multirow[t]{2}{*}{ Gender } & Female & 27 & 2.006 & 0.157 & 0.931 & 0.335 \\
\hline & Male & 44 & & & & \\
\hline \multirow[t]{2}{*}{$\begin{array}{l}\text { Duration of symptoms } \\
\text { (months) }\end{array}$} & $\begin{array}{l}\text { Short }(\leq \\
\left.\text { cutoffa }^{\mathrm{a}}\right)\end{array}$ & 32 & 0.725 & $0.391^{b}$ & 0.385 & $0.535^{\mathrm{b}}$ \\
\hline & $\begin{array}{l}\text { Long }(> \\
\left.\text { cutoffa }^{\mathrm{a}}\right)\end{array}$ & 39 & & & & \\
\hline \multirow[t]{2}{*}{ Tumor size (in diameter, cm) } & $\begin{array}{l}\text { Small }(\leq \\
\text { cutoffa) }\end{array}$ & 27 & 3.097 & $0.078^{b}$ & 3.838 & $0.050^{\mathrm{b}}$ \\
\hline & $\begin{array}{l}\text { Large }(> \\
\left.\text { cutoff }^{\mathrm{a}}\right)\end{array}$ & 44 & & & & \\
\hline \multirow[t]{2}{*}{ Type of resection } & Wide & 38 & 8.837 & 0.003 & 8.583 & 0.003 \\
\hline & Not wide & 33 & & & & \\
\hline \multirow[t]{2}{*}{ Surrounding tissue invasion } & No & 47 & 6.201 & 0.013 & 5.804 & 0.016 \\
\hline & Yes & 24 & & & & \\
\hline \multirow[t]{2}{*}{ Adjuvant radiotherapy } & No & 54 & 4.616 & 0.032 & 4.588 & 0.032 \\
\hline & Yes & 17 & & & & \\
\hline \multirow{2}{*}{$\begin{array}{l}\text { Preoperative sensory or motor } \\
\text { dysfunction }\end{array}$} & No & 58 & 0.050 & 0.823 & 0.007 & 0.934 \\
\hline & Yes & 13 & & & & \\
\hline $\begin{array}{l}\text { Postoperative sensory or } \\
\text { motor dysfunction }\end{array}$ & No & 33 & 3.415 & 0.065 & 6.054 & 0.014 \\
\hline
\end{tabular}

Bold values indicate $P<0.05 ; \mathrm{ABC}$, aneurysmal bone cyst; Vim, Vimentin; CK, cytokeratin. ${ }^{\mathrm{a}}$ Cutoff points for patient age, duration of symptoms, tumor size in the survival analysis of OS were 22, 5.0, 2.0 , respectively; ${ }^{b} \mathrm{P}$ value from the log-rank test was corrected as previously suggested. 


\begin{tabular}{|c|c|c|c|c|c|c|}
\hline \multirow[t]{2}{*}{ Factors } & \multirow[t]{2}{*}{ Categories } & \multirow[t]{2}{*}{ Numbers } & \multicolumn{2}{|c|}{$\begin{array}{l}\text { local recurrence- } \\
\text { free survival }\end{array}$} & \multicolumn{2}{|c|}{ overall survival } \\
\hline & & & $x^{2}$ & $P$-value & $x^{2}$ & $\begin{array}{l}P \\
\text { value }\end{array}$ \\
\hline & Yes & 38 & & & & \\
\hline \multirow[t]{2}{*}{ Secondary $A B C$} & No & 41 & 0.123 & 0.725 & 0.002 & 0.964 \\
\hline & Yes & 30 & & & & \\
\hline \multirow[t]{2}{*}{ Chicken-wire calcification } & No & 39 & 2.305 & 0.129 & 1.552 & 0.213 \\
\hline & Yes & 23 & & & & \\
\hline \multirow[t]{2}{*}{ Tumoral S100 expression } & Low & 14 & 0.001 & 0.969 & 0.001 & 0.979 \\
\hline & High & 57 & & & & \\
\hline \multirow[t]{2}{*}{ Tumoral Vim expression } & Low & 28 & 1.243 & 0.265 & 1.218 & 0.270 \\
\hline & High & 43 & & & & \\
\hline \multirow[t]{2}{*}{ Tumoral CK expression } & Low & 49 & 2.846 & 0.092 & 1.865 & 0.172 \\
\hline & High & 22 & & & & \\
\hline \multicolumn{7}{|c|}{ 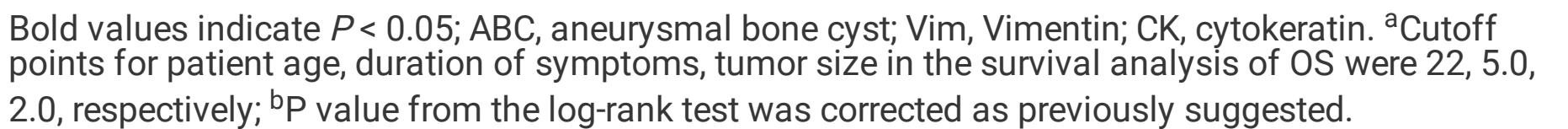 } \\
\hline
\end{tabular}


Table 5

Multivariate cox analyses of the prognostic factors of local recurrence-free survival and overall survival in patients with extra-axial chondroblastoma

\begin{tabular}{|c|c|c|c|c|c|c|}
\hline \multirow[t]{2}{*}{ Factors } & \multirow[t]{2}{*}{ Categories } & \multirow[t]{2}{*}{ Numbers } & \multicolumn{2}{|c|}{$\begin{array}{l}\text { local recurrence- } \\
\text { free survival }\end{array}$} & \multicolumn{2}{|c|}{ overall survival } \\
\hline & & & $\begin{array}{l}P \\
\text { value }\end{array}$ & $\begin{array}{l}\mathrm{HR}(95 \% \\
\mathrm{Cl})\end{array}$ & $\begin{array}{l}P \\
\text { value }\end{array}$ & $\begin{array}{l}\mathrm{HR} \\
(95 \% \mathrm{Cl})\end{array}$ \\
\hline \multirow[t]{2}{*}{ Type of resection } & Wide & 27 & 0.019 & $\begin{array}{l}4.774 \\
(1.295- \\
17.593)\end{array}$ & 0.039 & $\begin{array}{l}5.405 \\
(1.086- \\
26.901)\end{array}$ \\
\hline & Not wide & 34 & & & & \\
\hline \multirow[t]{2}{*}{ Surrounding tissue invasion } & No & 18 & 0.041 & $\begin{array}{l}3.052 \\
(1.048- \\
8.889)\end{array}$ & 0.102 & $\begin{array}{l}2.626 \\
(0.826- \\
8.344)\end{array}$ \\
\hline & Yes & 43 & & & & \\
\hline \multirow[t]{2}{*}{ Adjuvant radiotherapy } & No & 54 & 0.313 & $\begin{array}{l}1.739 \\
(0.593- \\
5.096)\end{array}$ & 0.365 & $\begin{array}{l}1.728 \\
(0.529- \\
5.639)\end{array}$ \\
\hline & Yes & 17 & & & & \\
\hline \multirow[t]{2}{*}{$\begin{array}{l}\text { Postoperative sensory or } \\
\text { motor dysfunction }\end{array}$} & No & 33 & l & / & 0.032 & $\begin{array}{l}0.242 \\
(0.066- \\
0.887)\end{array}$ \\
\hline & Yes & 38 & & & & \\
\hline
\end{tabular}

\section{Discussion}

\section{Key results}

In this study, we performed a comprehensive analysis of the largest ACB cohort and investigated the relationship between clinicopathological characteristics and patient survival. We also compared the differences in patient characteristics and prognostic factors between ACBC and EACB patients. We found that the age and tumor size were larger in ACB patients than in EACB patients, and the incidence of surrounding tissue invasion and postoperative sensory or motor dysfunction were also higher in $A C B$ patients. High expression of Vim was also seen more frequently in ACB patients. In both the ACB and EACB cohorts, the type of resection was associated with LRFS, and the type of resection and surrounding tissue invasion were associated with OS, but most other factors showed inconsistent survival between the two groups. 
The above findings suggest that ACB may have different molecular biological features and clinical behaviors than EACB. These data help us to gain a comprehensive understanding of the prognostic factors of $A C B$ so that reasonable prognostic risk stratification can be performed and patient survival can be improved.

\section{Differences in Immunohistopathological and Clinicopathological Characteristics Between ACB and EACB}

This study compared the differences in patient characteristics and prognostic patterns between ACB and EACB. We found similarities in the expression of most parameters between ACB and EACB, but the expression of Vim was higher in ACB. Overexpression of Vim, a major intermediate filament (IF) protein in mesenchymal cells, is closely associated with accelerated growth and infiltration and is a poor prognostic factor in many cancers ${ }^{18-21}$. Therefore, we hypothesized that ACB may be biologically more aggressive and have a higher recurrence rate than EACB. Similar to this hypothesis, it has been reported that spinal $\mathrm{CB}$ is more aggressive and more prone to recurrence than extremity bone $\mathrm{CB}^{9-11}$; in addition, our study also found that the size of tumors and the incidence of surrounding tissue invasion were greater in $A C B$ patients than in EACB patients, and a larger tumor size and higher surrounding tissue invasion rate indicated high tumor aggressiveness and poor prognosis ${ }^{22,23}$. In addition, ACB patients are also more likely to develop sensory or motor dysfunction, which is not difficult to understand. For anatomical reasons, the tumors in ACB patients tend to occur in the spine and skull, with tumors close to the neurovasculature, which also makes the risk of nerve damage considerably higher than that in EACB patients.

Furthermore, we found that the average age of ACB patients is greater than that of EACB patients, and interestingly, it has been reported in the literature that the majority of $C B$ patients are under 50 years of age, mainly affecting people aged $20-30$ years ${ }^{5,24}$, while the age of predilection for cranial CB patients is 40 years ${ }^{7}$. Regarding the site of occurrence, the most common site in young CB patients is the end of the long bones ${ }^{4}$, while in older patients, the preferred location of the tumor is more variable and may involve multiple sites, such as the craniofacial skeleton ${ }^{24,25}$. This could also explain the fact that the mean age of ACB patients is greater than that of EACB patients. However, further large sample data comparisons are needed for subsequent research analysis.

Influence of the type of resection and surrounding tissue invasion on the survival of ACB and EACB

Due to the aggressive nature of $\mathrm{CB}$, surgical treatment appears necessary ${ }^{5,10,26}$, and our study found that performing wide tumor resection resulted in good LRFS in patients, which is consistent with this finding. Most scholars recommend removing as much complete tumor tissue as possible to reduce postoperative recurrence rates and achieve good disease control ${ }^{5,10,26}$. A recent study on $C B$ of the spine also further confirmed the results of this study ${ }^{27}$. In addition, it has been reported that patients will have a high probability of tumor recurrence if residual lesions remain after surgery ${ }^{7}$. 
At the same time, our analysis found that patients with surrounding tissue invasion had shorter OS, which is not difficult to understand and is consistent with previously reported findings that if the tumor infiltration is extensive or the tumor itself is adjacent to important nerves, blood vessels, and other tissue structures, it is difficult to obtain wide resection of the tumor during surgery, thus making postoperative recurrence more likely in patients ${ }^{7,27}$. In addition, whether it is due to the long-term infiltration and destruction of the body by tumor tissues or damage to important neurovascular or tissue organs during surgery, patients who have the further aggravation of symptoms are likely to cause a decrease in their antitumor immune function, which also creates conditions for tumor recurrence and leads to an increased recurrence rate re-30. $^{28}$.

\section{Influence of chicken-wire calcification on the survival of ACB patients}

Chicken-wire calcification is widely present in the eosinophilic mechanism of CB and may serve as a diagnostic tissue feature of $\mathrm{CB}^{5,31,32}$. The present study is consistent with the results of a previous study from our integrative analysis, in which spinal CB patients with chicken-wire calcification expression have a better prognosis ${ }^{17}$. It has been shown that patients with calcification in the tumor tissue had significantly longer median progression-free survival and overall survival than patients without calcification ${ }^{33}$. Calcification is mainly the deposition of calcium salts and minerals, and bone bridging proteins are involved in the regulation of the calcification process ${ }^{34}$, while osteopontin can promote malignant tumor invasion, growth and metastasis ${ }^{35}$. Therefore, we speculate that the downregulation of osteopontin expression in tumors of ACB patients reduces their aggressiveness. In addition, it has even been found that even if different types of calcification exist in the tumor tissue of CB patients, the prognosis of patients with chicken-wire calcification is better than that of patients with nonchicken-wire calcification ${ }^{36}$, which may be related to the different biological behaviors arising from the different spatial arrangements, and all these theories deserve further investigation.

\section{Influence of Adjuvant Radiotherapy on the Survival of EACB}

Another major finding showed that patients with EACB treated with adjuvant radiotherapy had a worse prognosis, which is similar to previous reports that radiotherapy may lead to the transformation of $C B$ into a more malignant sarcoma $2,7,27$, and it has even been reported that any modality of adjuvant therapy is prohibited for $\mathrm{CB}^{37}$. In contrast, radiotherapy has been reported to reduce the tumor recurrence rate in patients and can be used in patients with postoperative recurrence and inoperable treatment, resulting in a good prognosis ${ }^{9}$. Therefore, the prognostic role of radiotherapy in CB remains controversial, and future studies with larger sample sizes and detailed information on patient radiotherapy combined with in vivo and in vitro experiments are needed to further evaluate the effects of adjuvant radiotherapy in patients with $\mathrm{CB}$. Current studies suggest that radiation promotes epithelial mesenchymal transformation and induces the production of new cancer stem cells from nonstem cells in various human cancers ${ }^{38,39}$. This idea may be the theoretical basis for the poor prognosis of CB patients receiving adjuvant 
radiotherapy, so the detection of newly generated cancer stem cells and their proteomic study may help to identify the precise mechanisms of progression in these CB patients.

\section{Limitation}

It is a retrospective study. However, future prospective studies with large samples and complete data records are still needed to further confirm the data of this study.

\section{Conclusion}

This study summarized the clinicopathological characteristics and prognostic factors of a large cohort of ACB patients and compared differences in patient characteristics and prognostic patterns between ACB and EACB. We found that ACB has similar characteristics to EACB except for having greater age and larger tumor size, as well as higher Vim expression, incidence of peripheral tissue infiltration, and postoperative sensory or motor dysfunction. The type of resection and invasion of surrounding tissues showed consistent prognostic impact in both groups, while ACB and EACB mainly showed different prognostic impacts. These data suggested that $A C B$ and EACB may have different molecular biological characteristics and clinical behavior, and these findings may help us to stratify the prognostic risk of ACB patients and guide the optimization of their treatment strategies.

\section{Declarations}

Ethics approval and consent to participate: The study protocol was approved by the Institutional Review Board of Second Xiangya Hospital of Central South University (CSU20201103), Hunan, China.

Consent for publication: Written informed consent was obtained from each patient for publication of this study. All presentations of case reports have consent to publish.

Availability of data and materials: Please contact author for data requests.

Funding: This work was supported by the National Natural Science Foundation of China (81871821 to JL and 82002364 MXZ), Project for Clinical Research of Hunan Provincial Health Commission (20201956 to MXZ) .

Competing interests: The authors declare that they have no competing interests.

Authors' contributions: All authors participated in data acquisition. BWZ, JL, ZHO and MXZ contributed to the conception and design of the study. BWZ, GHL and MXZ did the data analysis and interpretation. $\mathrm{HQN}, \mathrm{XBW}, \mathrm{BYZ}$ and MXZ contributed to drafting and revision of the manuscript. All authors read and approved the final manuscript.

Acknowledgements: We thank Dr. Yi Jiang and Dr. Xiao-Ling She from Department of Pathology, The Second Xiangya Hospital, Central South University for pathological analysis of the study. We also thank American Journal Experts for assistance in preparation of this manuscript. 


\section{References}

1. Tathe SP, Parate SN, Jaiswal KN, Randale AA. Intraoperative crush smear cytology of vertebral chondroblastoma: A diagnostic challenge. Diagn Cytopathol. 2018;46(1):79-82.

2. Angelini A, Hassani M, Mavrogenis AF, et al. Chondroblastoma in adult age. Eur J Orthop Surg Traumatol. 2017;27(6):843-9.

3. Lin PP, Thenappan A, Deavers MT, Lewis VO, Yasko AW. Treatment and prognosis of chondroblastoma. Clin Orthop Relat Res. 2005;438:103-9.

4. $\mathrm{Xu} \mathrm{H}$, Nugent $\mathrm{D}$, Monforte $\mathrm{HL}$, et al. Chondroblastoma of bone in the extremities: a multicenter retrospective study. J Bone Joint Surg Am. 2015;97(11):925-31.

5. Konishi E, Nakashima Y, Mano M, et al. Chondroblastoma of extra-craniofacial bones: Clinicopathological analyses of 103 cases. Pathol Int. 2017;67(10):495-502.

6. Laitinen MK, Stevenson JD, Evans S, et al. Chondroblastoma in pelvis and extremities- a signle centre study of 177 cases. J Bone Oncol. 2019;17:100248.

7. Muhammed A, Meshneb M, Saro H, Elnakib N, Elnakib E. Management of cranial chondroblastoma in adults; a pooled analysis. Am J Otolaryngol. 2020;41(4):102486.

8. Venkatasamy A, Chenard MP, Massard G, Steib JP, Bierry G. Chondroblastoma of the thoracic spine: a rare location. Case report with radiologic-pathologic correlation. Skeletal Radiol. 2017;46(3):36772.

9. Chung OM, Yip SF, Ngan KC, Ng WF. Chondroblastoma of the lumbar spine with cauda equina syndrome. Spinal Cord. 2003;41(6):359-64.

10. Ilaslan H, Sundaram M, Unni KK. Vertebral chondroblastoma. Skeletal Radiol. 2003;32(2):66-71.

11. Kim S, Cho K-J, Park Y, et al. Chondroblastoma of the Lumbar Spine - A Case Report and Review of the Literature. The Korean Journal of Pathology. 2011;45:532.

12. Zheng BW, Yang ML, Huang W, Zheng BY, Zhang TL, Li J, Lv GH, Yan YG, Zou MX. Prognostic Significance of Tumor-Associated Macrophages in Chondroblastoma and Their Association with Response to Adjuvant Radiotherapy. J Inflamm Res. 2021;17(14):1991-2005.

13. Bettegowda C, Yip S, Lo SL, et al. Spinal column chordoma: prognostic significance of clinical variables and T (brachyury) gene SNP rs2305089 for local recurrence and overall survival. Neuro Oncol. 2017;19(3):405-13.

14. Zou MX, Lv GH, Wang XB, et al. Clinical Impact of the Immune Microenvironment in Spinal Chordoma: Immunoscore as an Independent Favorable Prognostic Factor. Neurosurgery. 2019;84(6):E318-33.

15. Zou MX, Pan Y, Huang W, et al. A four-factor immune risk score signature predicts the clinical outcome of patients with spinal chordoma. Clin Transl Med. 2020;10(1):224-37.

16. Camp RL, Dolled-Filhart M, Rimm DL. X-tile: a new bio-informatics tool for biomarker assessment and outcome-based cut-point optimization. Clin Cancer Res. 2004;10(21):7252-9. 
17. Zheng BW, Huang W, Liu FS, Zhang TL, Wang XB, Li J, Lv GH, Yan YG, Zou MX. Clinicopathological and Prognostic Characteristics in Spinal Chondroblastomas: A Pooled Analysis of Individual Patient Data From a Single Institute and 27 Studies. Global Spine J. 2021;26:21925682211005732.

18. Du L, Li J, Lei L, et al. High Vimentin Expression Predicts a Poor Prognosis and Progression in Colorectal Cancer: A Study with Meta-Analysis and TCGA Database. Biomed Res Int. 2018;2018:6387810.

19. Liu S, Liu L, Ye W, et al. High Vimentin Expression Associated with Lymph Node Metastasis and Predicated a Poor Prognosis in Oral Squamous Cell Carcinoma. Sci Rep. 2016;6:38834.

20. Tadokoro A, Kanaji N, Liu D, et al. Vimentin Regulates Invasiveness and Is a Poor Prognostic Marker in Non-small Cell Lung Cancer. Anticancer Res. 2016;36(4):1545-51.

21. Tanaka K, Tokunaga E, Inoue $Y$, et al. Impact of Expression of Vimentin and Axl in Breast Cancer. Clin Breast Cancer. 2016;16(6):520-6.e522.

22. Shin $\mathrm{CH}$, Roh JL, Song DE, et al. Prognostic value of tumor size and minimal extrathyroidal extension in papillary thyroid carcinoma. Am J Surg. 2020;220(4):925-31.

23. Erdem S, Verep S, Bagbudar S, Ozluk Y, Sanli O, Ozcan F. The clinical predictive factors and postoperative histopathological parameters associated with upgrading after radical prostatectomy: A contemporary analysis with grade groups. Prostate. 2020;80(2):225-34.

24. Bloem JL, Mulder JD. Chondroblastoma: a clinical and radiological study of 104 cases. Skeletal Radiol. 1985;14(1):1-9.

25. Turcotte RE, Kurt AM, Sim FH, Unni KK, McLeod RA. Chondroblastoma. Hum Pathol. 1993;24(9):9449.

26. Sohn SH, Koh SA, Kim DG, et al. A case of spine origin chondroblastoma metastasis to lung. Cancer Res Treat. 2009;41(4):241-4.

27. Jia Q, Liu C, Yang J, et al. Clinical features, treatments and long-term follow-up outcomes of spinal chondroblastoma: report of 13 clinical cases in a single center. Journal of Neuro-Oncology. 2018;140(1):99-106.

28. Kao CH, Sun LM, Chen YS, et al. Risk of Nongenitourinary Cancers in Patients With Spinal Cord Injury: A Population-based Cohort Study. Medicine (Baltimore). 2016;95(2):e2462.

29. Zha J, Smith A, Andreansky S, Bracchi-Ricard V, Bethea JR. Chronic thoracic spinal cord injury impairs CD8+ T-cell function by up-regulating programmed cell death-1 expression. J Neuroinflammation. 2014;11:65.

30. Allison DJ, Ditor DS. Immune dysfunction and chronic inflammation following spinal cord injury. Spinal Cord. 2015;53(1):14-8.

31. Demirhan H, Acioğlu E, Durna YM, Yiğit Ö, Bozkurt ER, Karagöz Y. Temporal Bone Localized Chondroblastoma. J Craniofac Surg. 2015;26(8):e689-90.

32. Chen W, DiFrancesco LM. Chondroblastoma: An Update. Arch Pathol Lab Med. 2017;141(6):867-71. 
33. Zhou Y, Zhang J, Dan P, et al. Tumor calcification as a prognostic factor in cetuximab plus chemotherapy-treated patients with metastatic colorectal cancer. Anticancer Drugs. 2019;30(2):195200.

34. Steitz SA, Speer MY, McKee MD, et al. Osteopontin inhibits mineral deposition and promotes regression of ectopic calcification. Am J Pathol. 2002;161(6):2035-46.

35. Rangaswami H, Bulbule A, Kundu GC. Osteopontin: role in cell signaling and cancer progression. Trends Cell Biol. 2006;16(2):79-87.

36. John I, Inwards CY, Wenger DE, et al. Chondroblastomas presenting in adulthood: a study of 39 patients with emphasis on histological features and skeletal distribution. Histopathology. 2020;76(2):308-17.

37. Vukasinović Z, Spasovski D, Slavković N, et al. [Chondroblastoma--current opinion]. Srp Arh Celok Lek. 2006;134(11-12):567-70.

38. Li F, Zhou K, Gao L, et al. Radiation induces the generation of cancer stem cells: A novel mechanism for cancer radioresistance. Oncol Lett. 2016;12(5):3059-65.

39. Sun T, Yang W, Toprani SM, et al. Induction of immunogenic cell death in radiation-resistant breast cancer stem cells by repurposing anti-alcoholism drug disulfiram. Cell Commun Signal. 2020;18(1):36.

\section{Figures}




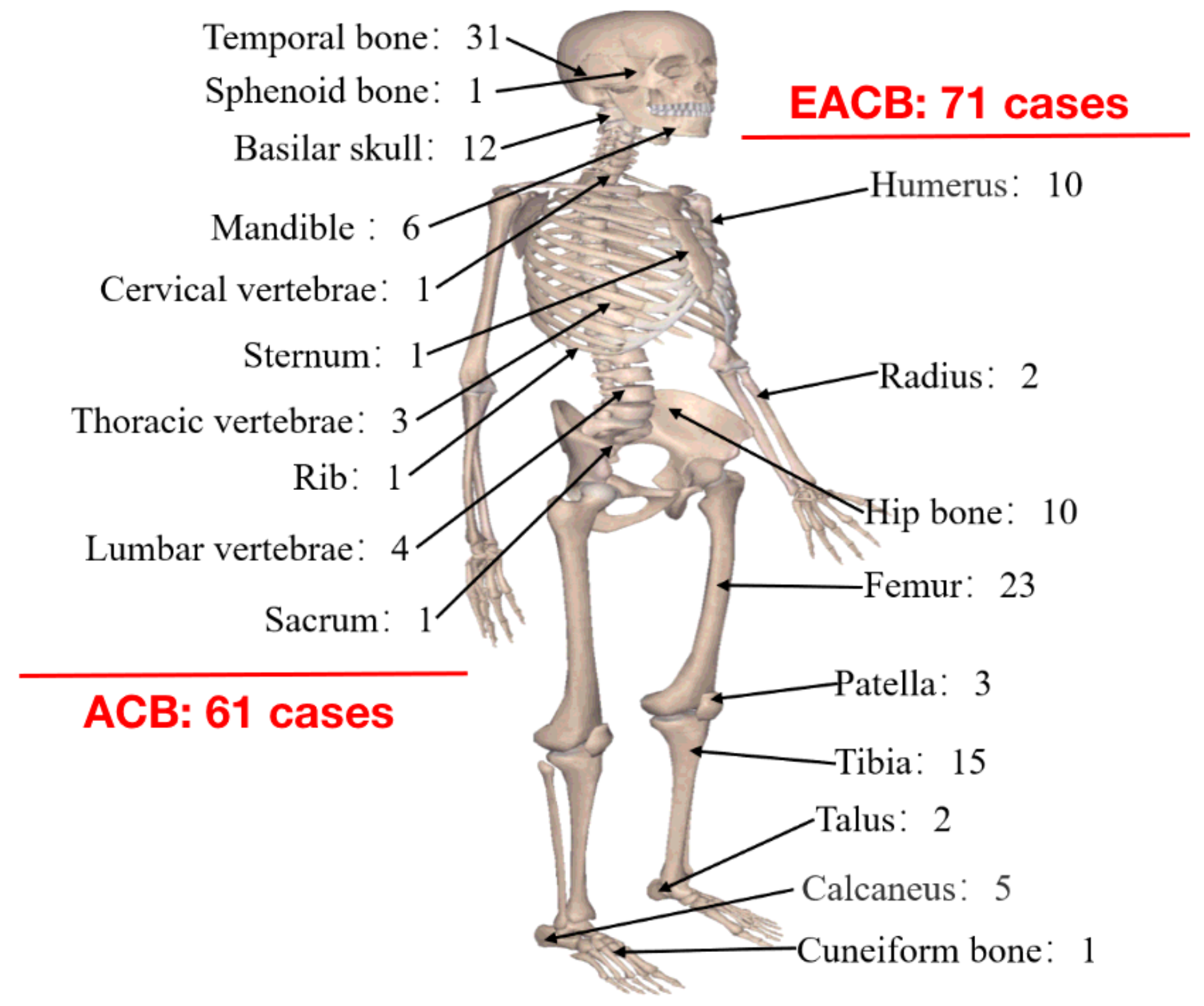

Figure 1

Distribution of the tumor site for 132 chondroblastoma patients. 

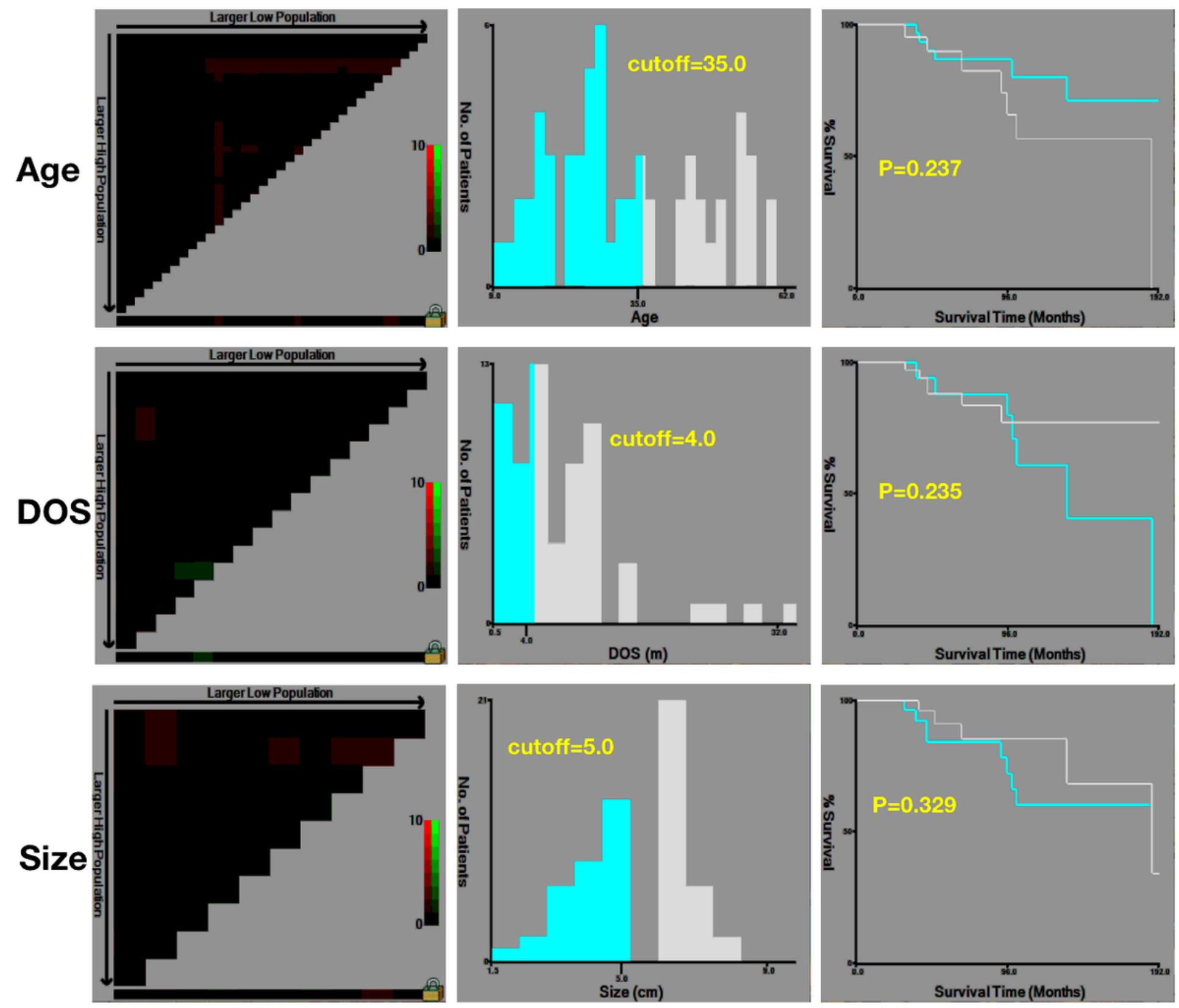

Figure 2

Determined cutoff values for age, duration of symptoms and tumor size in prognosis analysis of overall survival in axial chondroblastoma patients. DOS, duration of symptoms. 

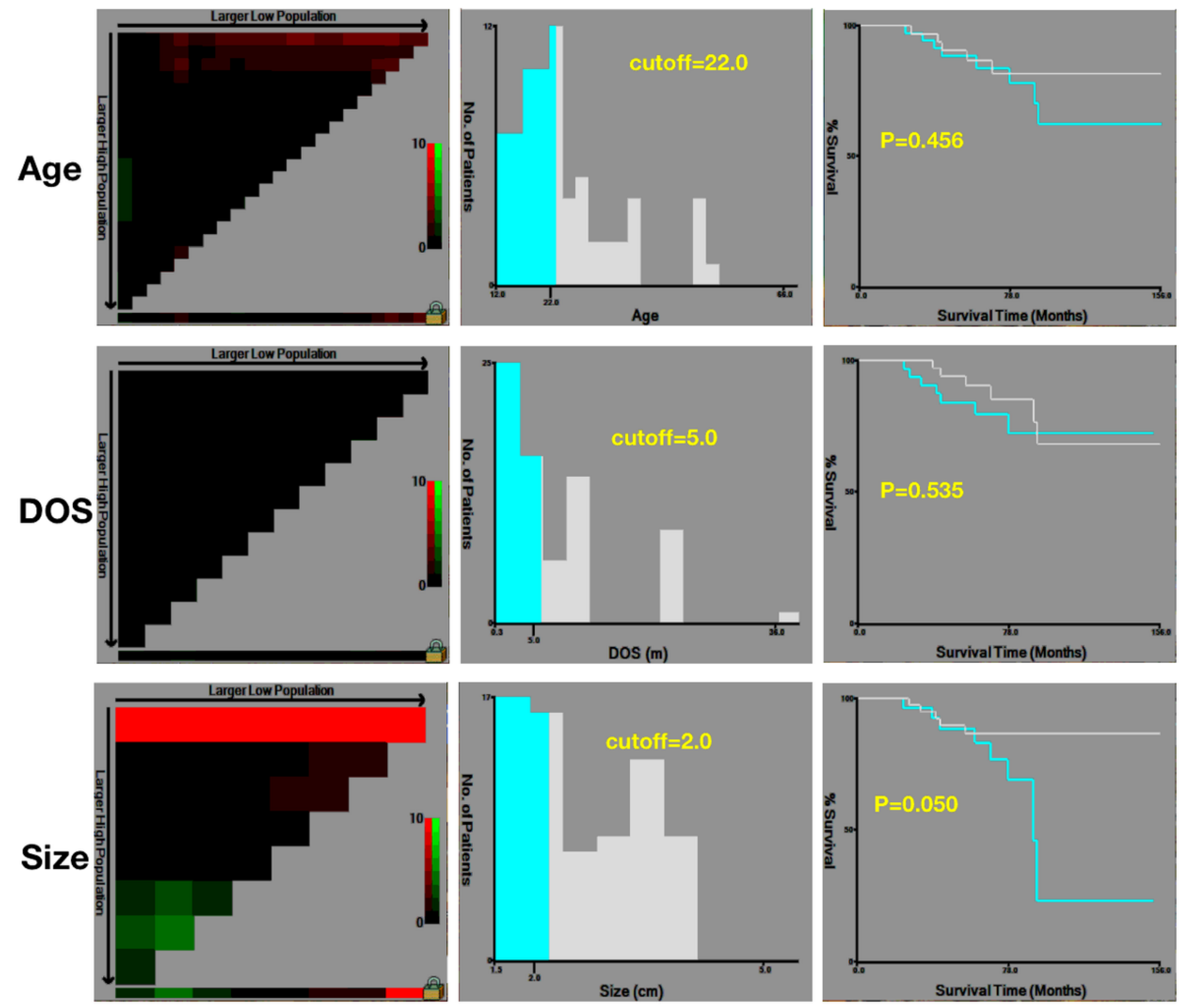

Figure 3

Determined cutoff values for age, duration of symptoms and tumor size in prognosis analysis of overall survival in extra-axial chondroblastoma. DOS, duration of symptoms. 

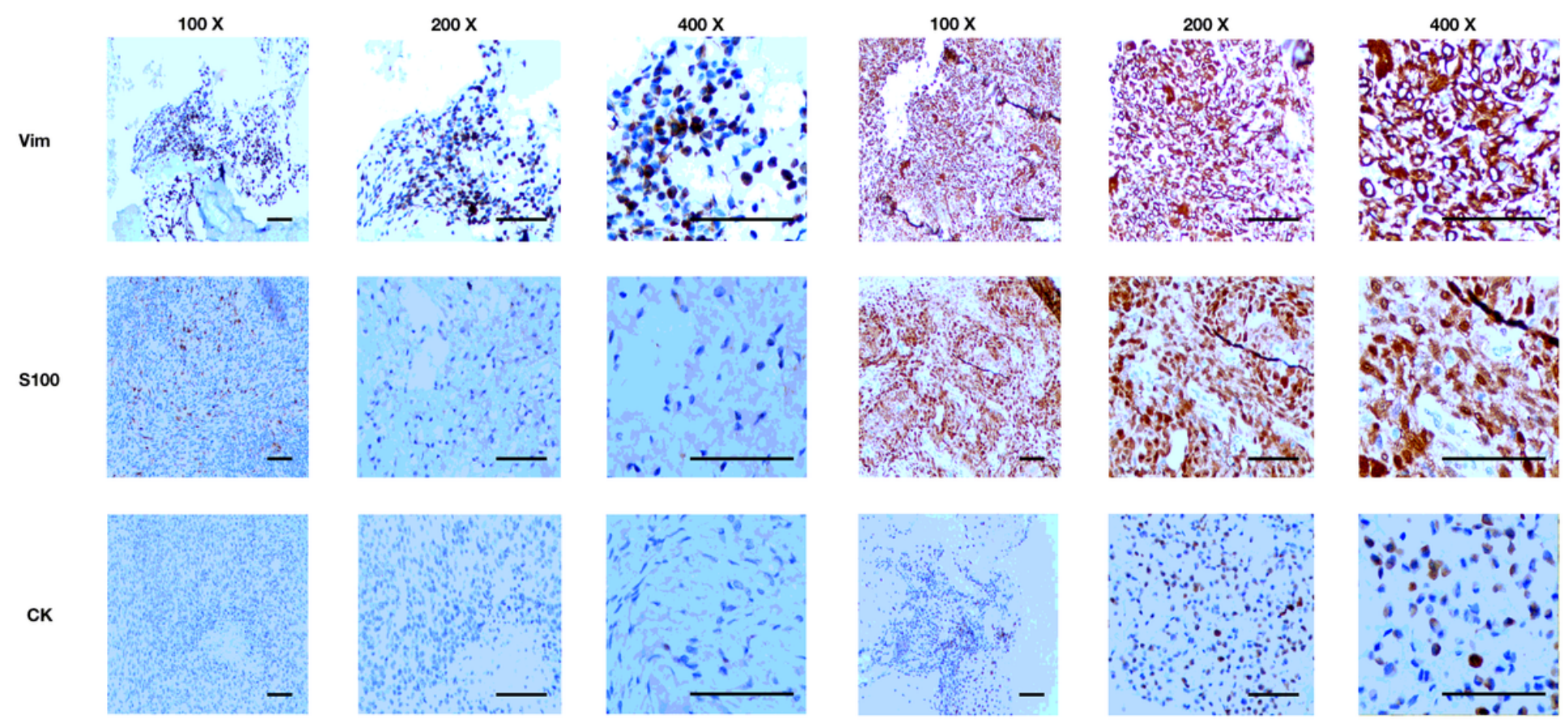

Low Expression

High Expression

\section{Figure 4}

Representative images of immunohistochemical markers in chondroblastoma tissues.

Vim, Vimentin; CK, cytokeratin. Scale bar $=100 \mu \mathrm{m}$.
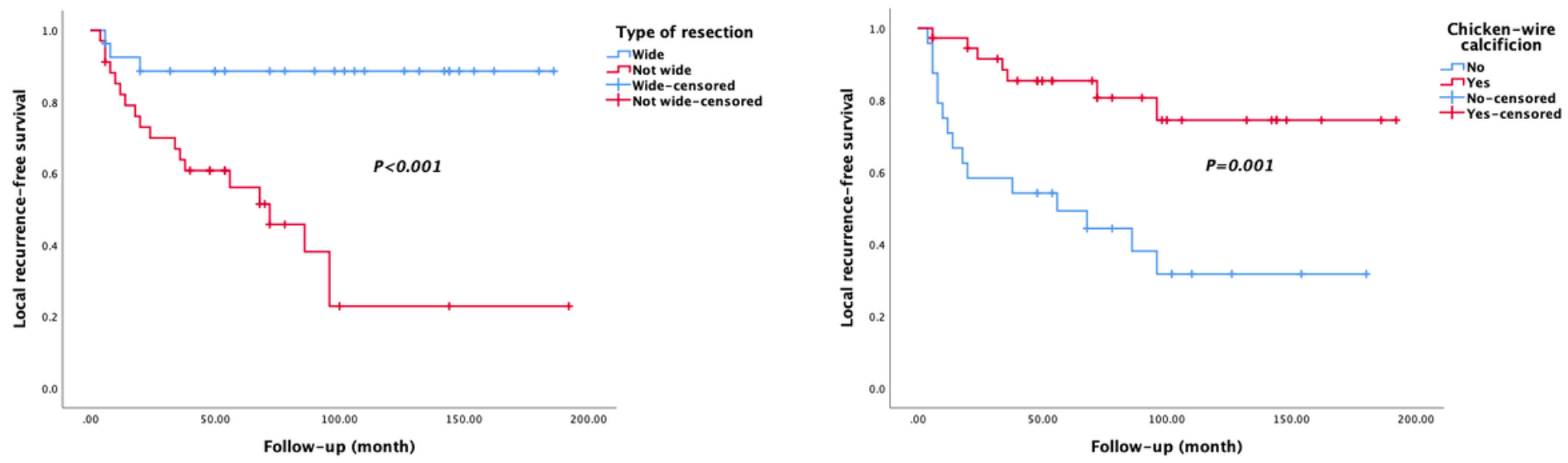

Figure 5

Kaplan-Meier curves of local recurrence-free survival of axial chondroblastoma patients stratified by type of resection and chicken-wire calcification. 

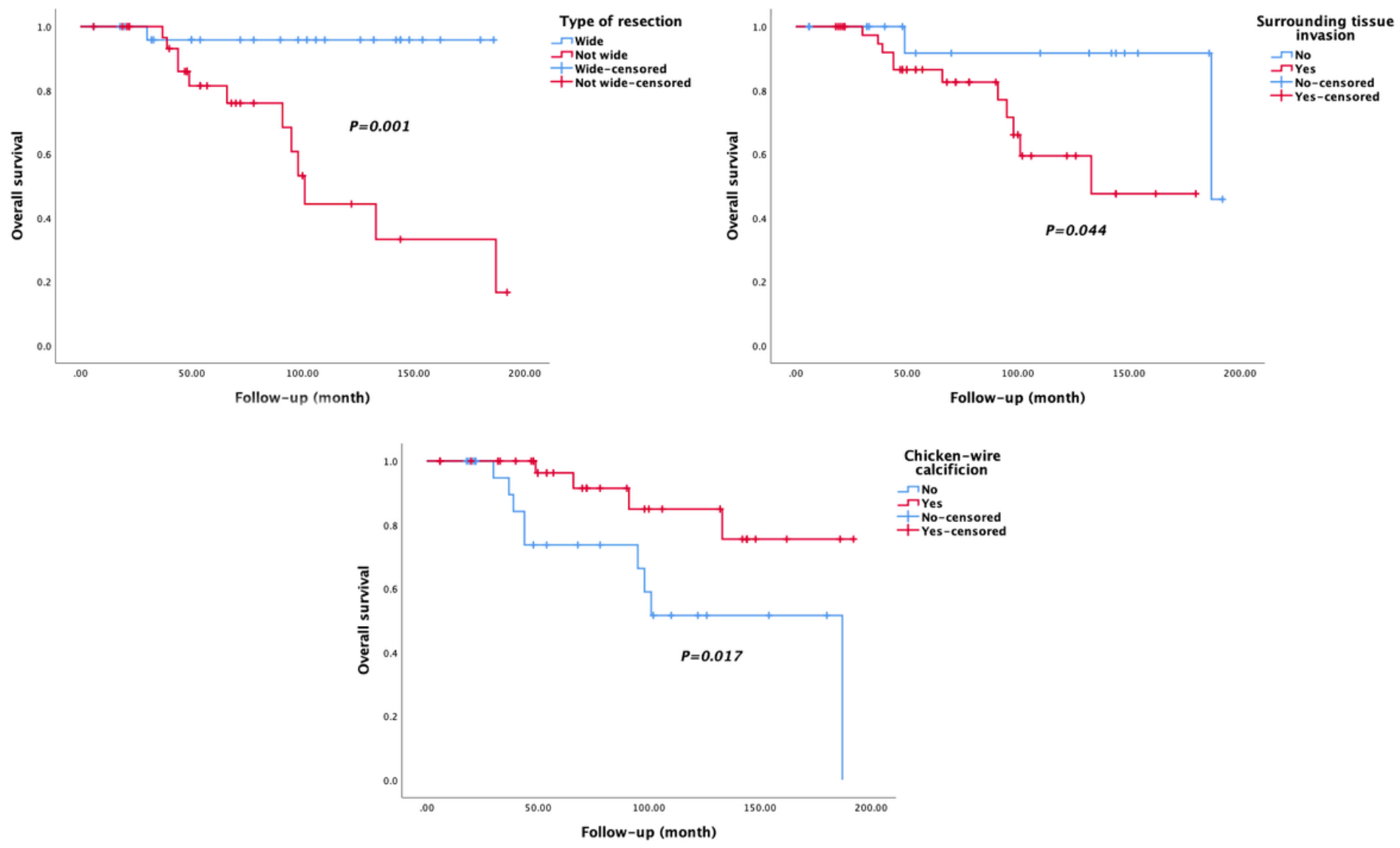

Figure 6

Kaplan-Meier curves of overall survival of axial chondroblastoma patients stratified by type of resection, surrounding tissue invasion and chicken-wire calcification. 

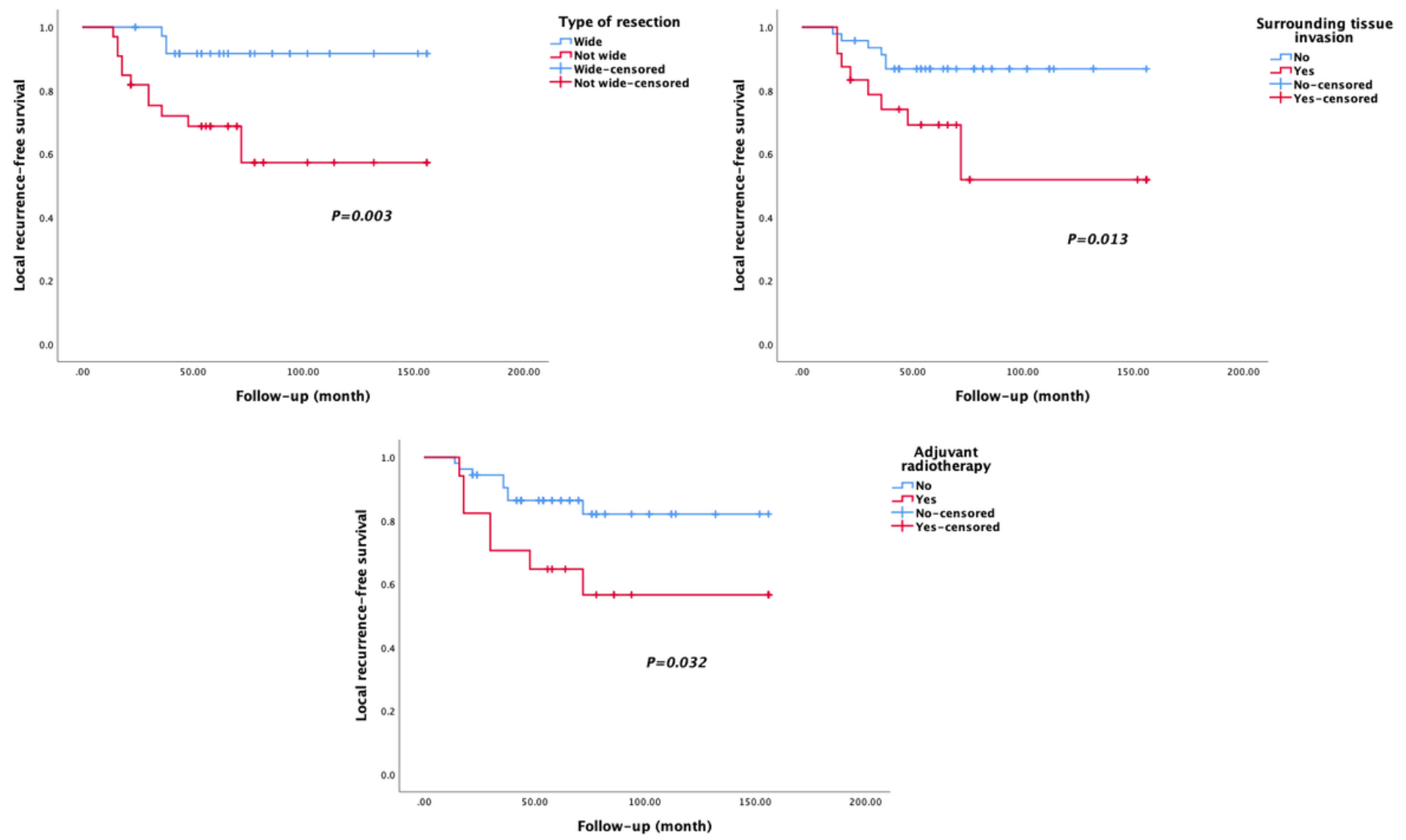

Figure 7

Kaplan-Meier curves of local recurrence-free survival of extra-axial chondroblastoma patients stratified by type of resection, surrounding tissue invasion and adjuvant radiotherapy. 

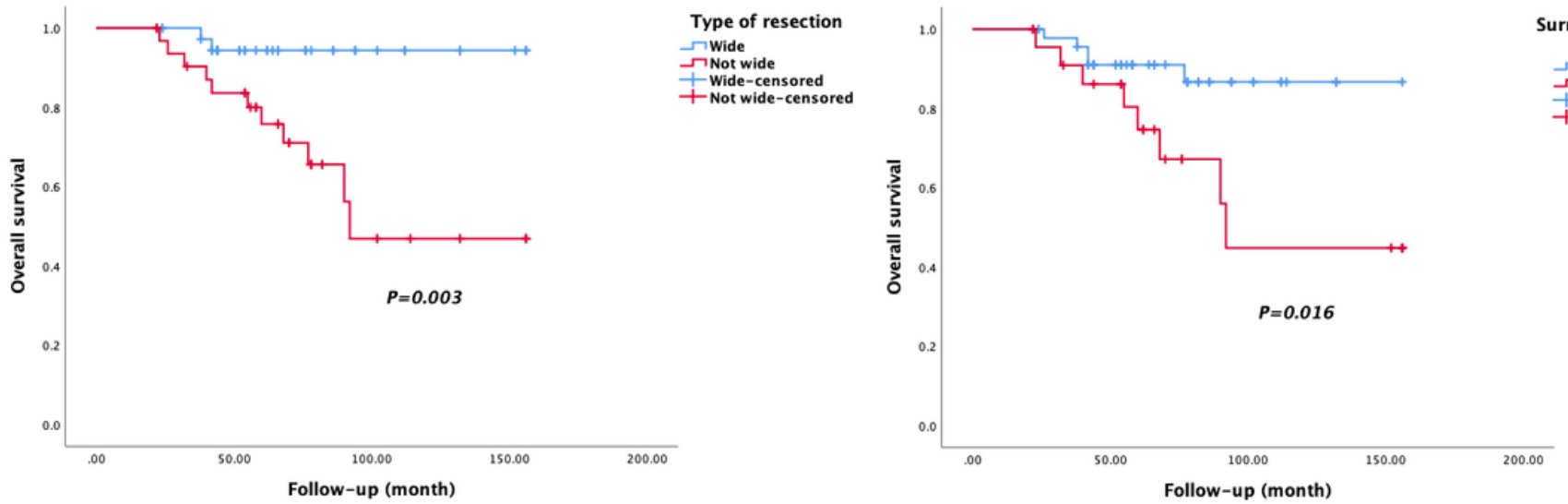

Surrounding tissue invasion

ITNes

+No-censored

+Yes-censored
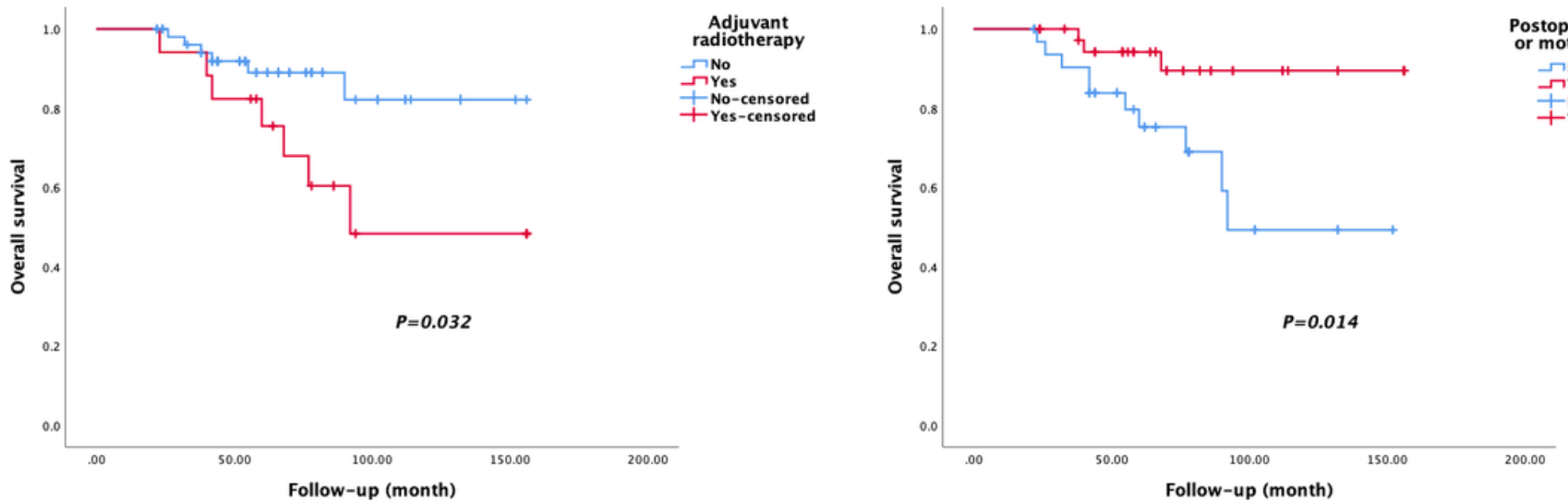

Figure 8

Kaplan-Meier curves of overall survival of extra-axial chondroblastoma patients stratified by type of resection, surrounding tissue invasion, adjuvant radiotherapy and postoperative sensory or motor dysfunction. 